\title{
MeThodology FOR DETERMINING DRY PORT SYSTEM TRANSPORT NETWORK - CASE STUDY PORT OF RIJEKA - ZAGREB
}

\author{
MLINARIC, T.J.; RogiC, K. \& RoZIC, T.
}

Abstract: One of the key elements for the efficient operation of intermodal terminals of a transport network with a certain number of ports is a high-quality dry ports system in their hinterland. In order to determine their optimal number, their technical and technological characteristics and their associated logistics subsystem must be viewed complementary in terms of infrastructure and performance. The methodology that was established for this purpose was made on a number of case studies of which the most important one is related to Zagreb as a dry port of the Port of Rijeka. The proposed methodology was evaluated based on the pre-defined technical, technological and economic criteria. In elaborating the presented methodology all the relevant research on this topic, both in Croatia and in Europe, have been used.

Key words: dry port, port of Rijeka, dry port methodology
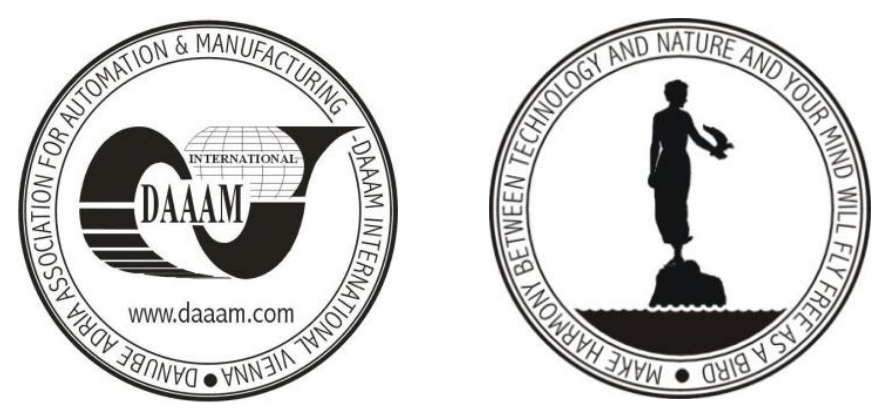

Authors' data: Dr. Sc. Mlinaric, T[omislav] J[osip]; Dr. Sc. Rogic, K[ristijan]; Rozic, T[omislav], Faculty of Transport and Traffic Sciences - University of Zagreb, Vukelićeva 4, 10000, Zagreb, mlinaric@fpz.hr, rogick@fpz.hr, tomislav.rozic@fpz.hr

This Publication has to be referred as: Mlinaric, T[omislav] J[osip]; Rogic, K[ristijan] \& Rozic, T[omislav] (2011). Methodology for Determining Dry Port System Transport Network - Case Study Port of Rijeka - Zagreb, Chapter 11 in DAAAM International Scientific Book 2011, pp. 133-146, B. Katalinic (Ed.), Published by DAAAM International, ISBN 978-3-901509-84-1, ISSN 1726-9687, Vienna, Austria

DOI: $10.2507 /$ daaam.scibook.2011.11 


\section{Introduction}

This paper presents the methodology of determining the network of dry port terminals in real environment. For this purpose the problem of positioning the dry port for the requirements of the most important seaport in the Republic of Croatia, the Port of Rijeka, has been dealt with. The technological and logistic background used to develop the mentioned methodology referred primarily to the study of goods flows on the considered traffic route in order to determine the existing volume and structure of the goods flows and their forecasts.

Based on this analysis the modal split in the existing traffic situation has been additionally developed, and certain expectations have also been presented regarding the way in which this modal split will behave independently of our activities of shifting a certain transport volume from one traffic subsystem to another. Furthermore, it has been taken into consideration that proactive ${ }^{1}$ traffic policy on the basis of strategic guidelines from the White Paper in accordance with the traffic development strategy of the Republic of Croatia the shift of a certain transportation volume would be carried out from road subsystem to the railways. Such approach required additionally technical and technological analyses in order to determine whether such volume is feasible in relation to the available capacities.

It is precisely this analysis that contains the basic elements of the proposed methodology, since the technical and technological parameters were studied for this purpose:

- the existing goods flows internal and external including transit;

- the development level of the traffic network and possibilities of merging into the main roads, depth of the aquatorium in port terminals, connection with at least two branches of transport (road and railway);

- the impact on the environment;

- the size of areas planned for the terminal (i.e. future dry port).

Based on the analysis of the mentioned criteria the proposed methodology has been described in detail and additionally tested for the needs of determining the dry port of the Port of Rijeka.

In the previous research of the problem presented in this paper, the great majority of authors have focused on the analysis of the individual parameters to define the network of dry port systems, whereas such an integral approach was very rare and did not give such a result as the one obtained by testing the proposed methodology on the case study of the Rijeka traffic route. Naturally, further studies will approach solving of this problem on the system network of the Republic of Croatia (cargo centre Zagreb, cargo centre Osijek...) and its immediate environment, and further with the aim of integration of the network of the dry port systems at the level of integrated traffic system of EU.

\footnotetext{
${ }^{1}$ Traffic policy with which the Republic of Croatia would stimulate shift of freight from road subsystem to an environmentally-friendlier subsystem
} 


\section{Determining the traffic demand}

The basic element of the proposed methodology is precise determination of the traffic demand on the observed traffic route. In this sense, when observing the current situation in the traffic system of the Republic of Croatia the road traffic subsystem has been specially analysed (Fig. 1).

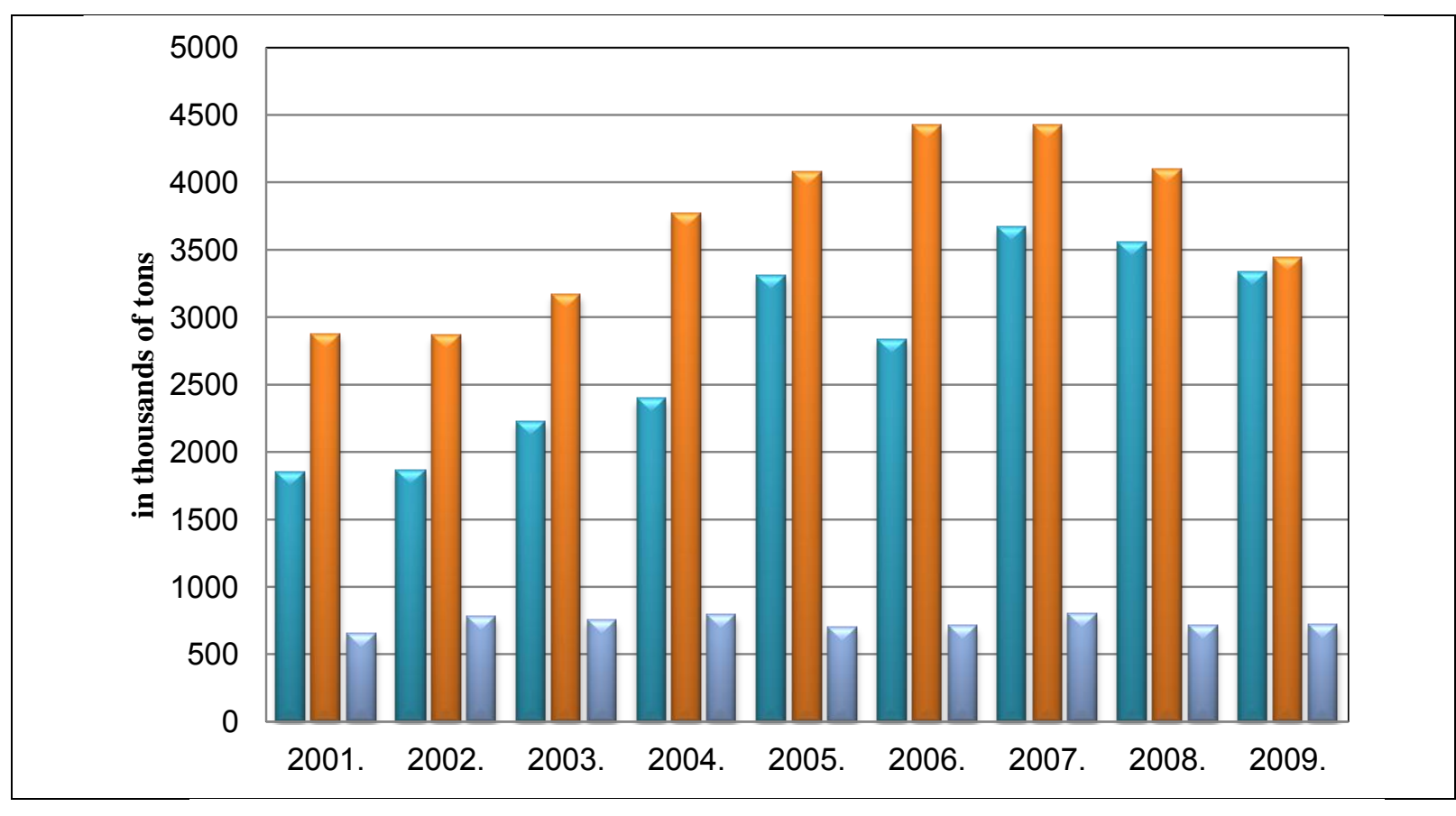

घDelivered abroad

arrived from abroad

⿶Transport abroad

Fig. 1. International road transport of goods in the Republic of Croatia

Fig. 1 shows that the goods arriving from foreign countries had the greatest influence on the increase of the total amount of the goods carried by road. These data confirm the thesis about the connection between the BDP increase with the increase in the level of consumption. This also refers to the data about the reduction of international transport of goods for the year 2009 which shows a decline in the amount of goods delivered from the foreign countries, and this fall can be characterised as the consequence of the global economic crisis.

Next, the rail and sea transport and short sea shipping are analysed in relation to the realised results in road traffic subsystem in the Republic of Croatia (Table 1).

According to Table 1 road transport of goods accounts for the most share in the transport of goods in the Republic of Croatia. The period between 2005 and 2008 marked a constant growth, whereas the only decline occurred in 2009, the year of crisis. The sea transport and short sea shipping also marked moderate constant growth until 2008, but since global crisis hit first this traffic subsystem, its decline started a bit earlier than in road transport of goods. However, the recovery in the quantities of the carried goods also started earlier than in other traffic subsystems. Although the most efficient and environmentally the friendliest, the railway system has marked the lowest quantity of the carried goods in relation to the abovementioned subsystems, and the reasons can be found in insufficient quality of the railway infrastructure on the observed Port of Rijeka - Zagreb section. The road transport in the Republic of Croatia is expected to maintain its share on the transportation market. 
Mlinaric, T.J.; Rogic, K. \& Rozic, T.: Methodology for Determining Dry Port Syst...

\begin{tabular}{|c|c|c|c|c|c|c|}
\hline & \multicolumn{2}{|c|}{ Railway transport } & \multicolumn{2}{c|}{ Road transport } & \multicolumn{2}{c|}{$\begin{array}{c}\text { Sea transport and short } \\
\text { sea shipping }\end{array}$} \\
\hline Year & $\begin{array}{c}\text { transported } \\
\text { goods, } \\
\text { thou. } \mathrm{t}\end{array}$ & $\begin{array}{c}\text { ton } \\
\text { kilometres, } \\
\text { mil. }\end{array}$ & $\begin{array}{c}\text { transported } \\
\text { goods, } \\
\text { thou. } \mathrm{t}\end{array}$ & $\begin{array}{c}\text { ton } \\
\text { kilometres, } \\
\text { mil. }\end{array}$ & $\begin{array}{c}\text { transported } \\
\text { goods, } \\
\text { thou. } \mathrm{t}\end{array}$ & $\begin{array}{c}\text { kilometres, } \\
\text { mil. }\end{array}$ \\
\hline 2005 & 14,333 & 2,835 & 58,886 & 9,328 & 29,975 & 126,064 \\
\hline 2006 & 15,395 & 3,305 & 63,840 & 10,175 & 31,423 & 136,994 \\
\hline 2007 & 15,764 & 3,574 & 66,814 & 10,502 & 32,420 & 137,474 \\
\hline 2008 & 14,851 & 3,312 & 110,812 & 11,042 & 30,768 & 142,972 \\
\hline 2009 & 11,651 & 2,641 & 92,847 & 9,429 & 31,371 & 137,345 \\
\hline
\end{tabular}

Tab. 1. Total quantities of transported goods through the territory of the Republic of Croatia

According to EU research, which means that one of the strategic objectives in the functioning of the dry port systems is such a modal split, that they will be capable of course to process the railway traffic increase in itself, which will be supplemented still by a certain transport volume as consequence of shifting freight from road to railways. In this sense the railway traffic subsystem has to be analysed as part of the intermodal transport chain in the function of dry port of a port.

Based on the abovementioned data additional analyses have been carried out, which means forecasting of the transport of goods per observed traffic subsystems. Considering railway traffic, the market of transport services has been additionally segmented, so that primarily the expectations in the transport of goods on the domestic market have been studied (Table 2).

Table 2 shows the transport of domestic goods in railway transport towards three possible scenarios, the pessimistic, realistic and optimistic one. The mentioned scenarios are characterised by very small quantities of the transported freight, but also what is most worrying, the relatively poor increase of the quantity of the transported freight, which can be connected with the current economic condition in Croatia, which is the main reason for the slow growth of the transport of goods.

Also, the forecast for the transport of goods in international rail transport for the three possible scenarios was carried out (Table 3).

\begin{tabular}{|c|c|c|c|c|c|}
\hline $\begin{array}{c}\text { Transport of } \\
\text { domestic } \\
\text { goods } \\
\text { on HŽ } \\
\text { network }\end{array}$ & 2008 & 2015 & 2020 & 2025 & 2028 \\
\hline Pessimistic & & $3,000,000$ & $3,080,000$ & $3,230,000$ & 3,390000 \\
\hline Realistic & $3,045,816$ & $3,230,000$ & $3,390,000$ & $3,800,000$ & $4,000,000$ \\
\hline Optimistic & & $3,390,000$ & $3,800,000$ & $4,390,000$ & $4,800,000$ \\
\hline
\end{tabular}

Tab. 2. Forecast of the transport of domestic goods for the period $2008-2028$ (ca. in tons) 


\begin{tabular}{|c|c|c|c|c|c|}
\hline $\begin{array}{c}\text { Transport of } \\
\text { international } \\
\text { goods on HŽ } \\
\text { network }\end{array}$ & 2008 & 2015 & 2020 & 2025 & 2028 \\
\hline Pessimistic & & $12,500,000$ & $14,062,000$ & $15,625,000$ & $15,937,000$ \\
\hline Realistic & $13,138,118$ & $13,125,000$ & $15,937,000$ & $18,125,000$ & $19,375,000$ \\
\hline Optimistic & & $13,750,000$ & $17,187,000$ & $20,625,000$ & $22,500,000$ \\
\hline
\end{tabular}

Tab. 3. Forecast of transport of international goods for the period $2008-2028$ (ca. in tons)

The transport forecast of the goods in international transport is somewhat more optimistic, first of all due to the integration of the Republic of Croatia into EU and the expected integration of its main traffic flows into the EU traffic flows. The largest part of the forecast traffic increase refers precisely to the most important traffic routes in Croatia, which certainly means also the Rijeka - Zagreb route.

\section{Modal split}

Before the mentioned forecast of the goods transport in the Croatian traffic system, a slower but continuous increase has been predicted, that will certainly reflect on the considered route. As the starting point, if the shares of transport regarding traffic subsystems on the considered route were to stay the same, the situation could proceed according to the simulation presented in Table 6 .

The analysis of the volume of container transport in the Port of Rijeka and at the container terminal Vrapče, shows that the oscillations in the number of handled containers at one and at the other terminal are time-connected, which supports the assumption about the dependence of turnover at the container terminal Vrapče with the turnover realised at the Port of Rijeka.

The Port of Rijeka recorded the maximum turnover in 2007 when about 175,000 container units were handled. In the same year the turnover of containers at the terminal Vrapče reached the highest level of about 17,000 container units. Since turnover forecasts at the container terminal of the Port of Rijeka predict an increase in the container turnover towards a level of about 250,000 container units annually in the following mid-term period, there is the need to construct a hinterland container terminal of higher capacity than the existing capacity at Vrapče.

\begin{tabular}{|c|c|c|c|c|c|c|c|c|c|}
\hline & 2001 & 2002 & 2003 & 2004 & 2005 & 2006 & 2007 & 2008 & 2009 \\
\hline TEU & 4,988 & 5,939 & 5,538 & 8,520 & 10,947 & 14,271 & 18,412 & 17,009 & 12,087 \\
\hline$\%$ & & $18.98 \%$ & $-7.24 \%$ & $53.84 \%$ & $28.48 \%$ & $30.37 \%$ & $29.02 \%$ & $-8.25 \%$ & $-28.93 \%$ \\
\hline
\end{tabular}

Tab. 4. Operation of the terminal Vrapče

Table 4 shows that the number of handled containers at that terminal in 2009 fell to the 2006 level. Taking into consideration the number of manipulated 
Mlinaric, T.J.; Rogic, K. \& Rozic, T.: Methodology for Determining Dry Port Syst...

containers at the terminal Vrapče in relation to the Port of Rijeka, then one could say that at the terminal Vrapče about $10 \%$ of the total number of containers at the Port of Rijeka were handled. Taking into consideration also the empirical data according to which the container turnover at the terminal Vrapče is $90 \%$ connected with the Port of Rijeka, a clear relation can be obtained between the future forecasts about the movement of freight in the Port of Ploče and the needs for the capacities of the terminal Vrapče.

\begin{tabular}{|c|c|c|c|}
\hline Year & Turnover of the Port of Rijeka & \multicolumn{2}{|c|}{ Carried by rail } \\
\hline 2001 & 17,852 & 4,843 & $27.1 \%$ \\
\hline 2002 & 18,078 & 5,135 & $28.4 \%$ \\
\hline 2003 & 28,298 & 8,852 & $31.3 \%$ \\
\hline 2004 & 60,864 & 15,414 & $25.3 \%$ \\
\hline 2005 & 76,258 & 17,234 & $22.6 \%$ \\
\hline 2006 & 94,390 & 21,811 & $23.1 \%$ \\
\hline 2007 & 145,040 & 36,050 & $24.9 \%$ \\
\hline 2008 & 168,761 & 42,485 & $25.2 \%$ \\
\hline 2009 & 175.000 & & \\
\hline
\end{tabular}

Tab. 5. Share of railways in the transport of containers to/from the Port of Rijeka

The question is whether a shift of additional volume of container transport in accordance with the expectations can be realised to the rail traffic subsystem in the function of dry port. The volume of the expected shift of container traffic to rail traffic subsystem is presented in Table 6 .

\begin{tabular}{|l|c|c|c|}
\hline & Railway transport & Road transport & $\begin{array}{c}\text { Sea transport (Port of } \\
\text { Rijeka) }\end{array}$ \\
\hline Year & $\begin{array}{c}\text { Number of } \\
\text { containers }\end{array}$ & Number of containers & Number of containers \\
\hline 2008 & 17,009 & 151,752 & 168,761 \\
\hline 2013 & 12,600 & 112,400 & 125,000 \\
\hline 2014 & 13,104 & 116,896 & 130,000 \\
\hline 2015 & 15,120 & 134,880 & 150,000 \\
\hline 2016 & 16,128 & 143,872 & 160,000 \\
\hline 2017 & 18,144 & 161,856 & 180,000 \\
\hline 2018 & 20,160 & 179,840 & 200,000 \\
\hline
\end{tabular}

Tab. 6. Forecast of container transport by road, rail and sea subsystem from the Port of Rijeka to container terminal Vrapče for the period 2008 - 2018 (ca. number of containers)

The authors have assumed that it is realistic to expect that with the proactive traffic policy at the annual level approximately $10 \%$ of container traffic could be 
shifted to rail subsystem. The proposed methodology presented further in this paper based on the pre-determined criteria will provide answer to the question whether this is technologically feasible.

\section{Methodology of determining capacity of traffic infrastructure in the function of the dry ports system}

The methodology proposed by the authors of this paper had not been presented before in such integral form to the wider scientific and professional public, neither in the Republic of Croatia, nor wider. The previous studies and scientific and professional papers, namely, have studied in great detail and very well the individual parameters (Roso, 2009; Ferrari et al., 2010; Notteboom, 2010), but such approach which forms the methodology for determining the network of dry ports systems based on their correlation is one of the first. The criteria whose correlation has been studied are presented in Table 7.

\begin{tabular}{|c|c|}
\hline & Criteria determining geo-traffic position and catchment area \\
\hline 1. & Existing goods flows internal and external including transit \\
\hline 2. & $\begin{array}{c}\text { Level of development of traffic network and possibilities of integrating into main traffic } \\
\text { routes, depth of the aquatorium in port terminals, connecting with at least two traffic } \\
\text { branches (road and railway) }\end{array}$ \\
\hline 3. & Impact on the environment \\
\hline 4. & Size of areas planned for the terminal \\
\hline
\end{tabular}

Tab. 7. Overview of criteria for determining the catchment area

\subsection{Existing goods flows internal and external including transit}

The traffic Corridors X and VII are the most important traffic connections that via Croatia form a part of the European traffic longitudinal corridors in the East West direction, that via Croatia connect Western and North-western Europe with Eastern and South-eastern Europe. The traffic connections to the traffic Corridor V, $\mathrm{Vb}$ and $\mathrm{Vc}$ belong to the major transversal corridors in the North - South direction, that via Croatia connect Northern (Baltic and Scandinavia) with Southern Europe (the Mediterranean).

If major junctions are analysed, which are in contact with the mentioned Corridors, one can see that the routes of all the Pan-European Corridors and their branches pass through Zagreb (of those that pass through Croatia) except for Corridors VII and Vc (Fig.s 2 and 3).

The structure and intensity of goods flows on a certain area are one of the major criteria for the selection of the dry port terminal macrolocation. The reasons that condition this criterion are the reduction of the distribution costs and safety of supply of a certain market or part of the market. 
Mlinaric, T.J.; Rogic, K. \& Rozic, T.: Methodology for Determining Dry Port Syst...

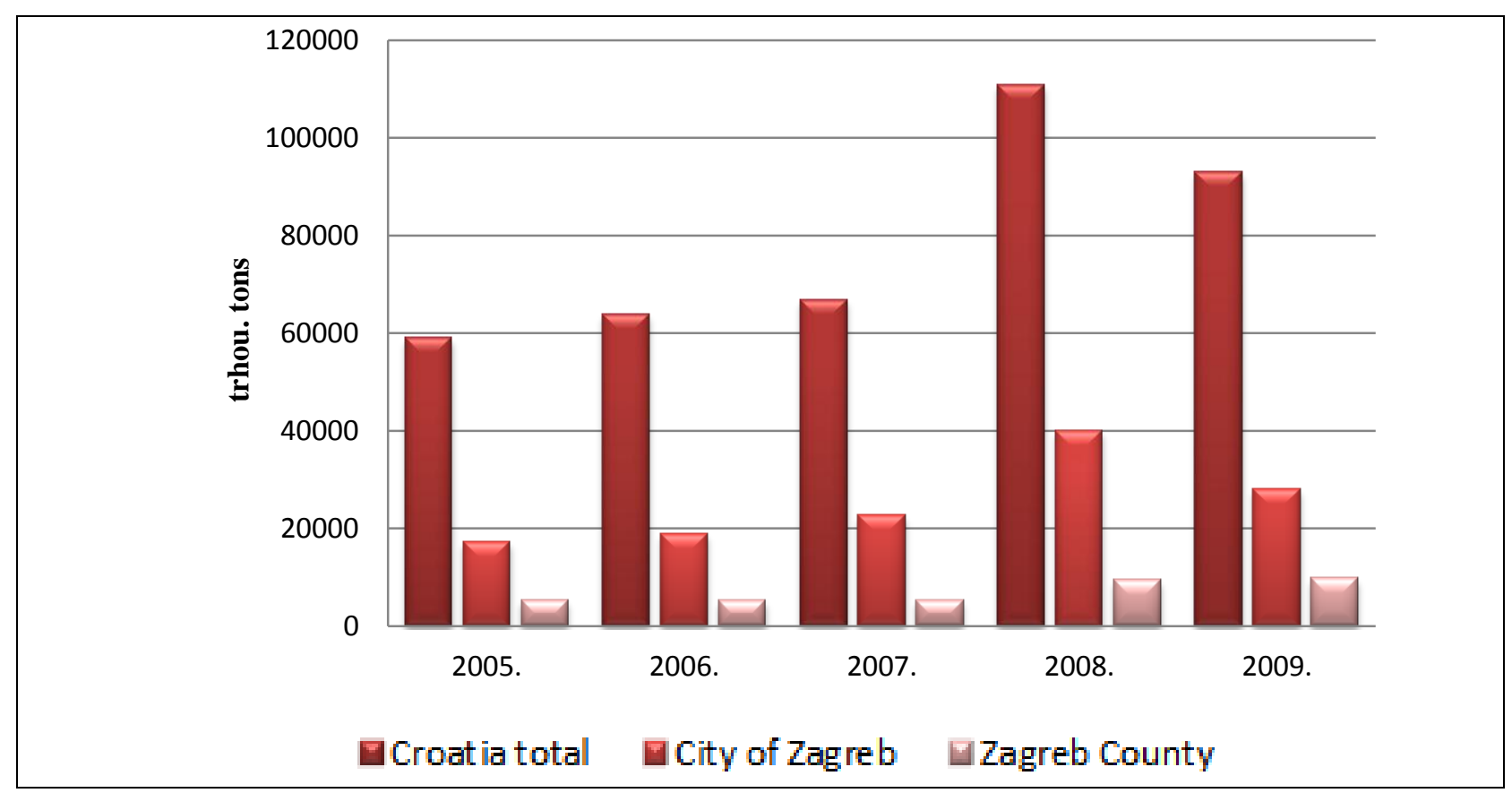

Fig. 2. Road transport of goods for the City of Zagreb and the Zagreb County

\begin{tabular}{|l|c|c|c|}
\hline Ton $\mathrm{km}$ & 2008 & 2009 & 2010 \\
\hline Total & $937,765.95$ & $980,831.4$ & $929,965.1$ \\
\hline Internal transport & $591,275.4$ & $589,168.9$ & $593,514.7$ \\
\hline International transport & $346,490.55$ & $391,662.5$ & $336,450.4$ \\
\hline Delivered abroad & $127,429.92$ & $139,798.5$ & $84,276.36$ \\
\hline Arrived from abroad & $131,619.06$ & $170,673.7$ & 154,287 \\
\hline $\begin{array}{l}\text { Transport for third } \\
\text { countries }\end{array}$ & $87,441.57$ & $81,190.36$ & $97,887.04$ \\
\hline
\end{tabular}

Tab. 8.Total volume of carried goods in ton kilometres for the City of Zagreb

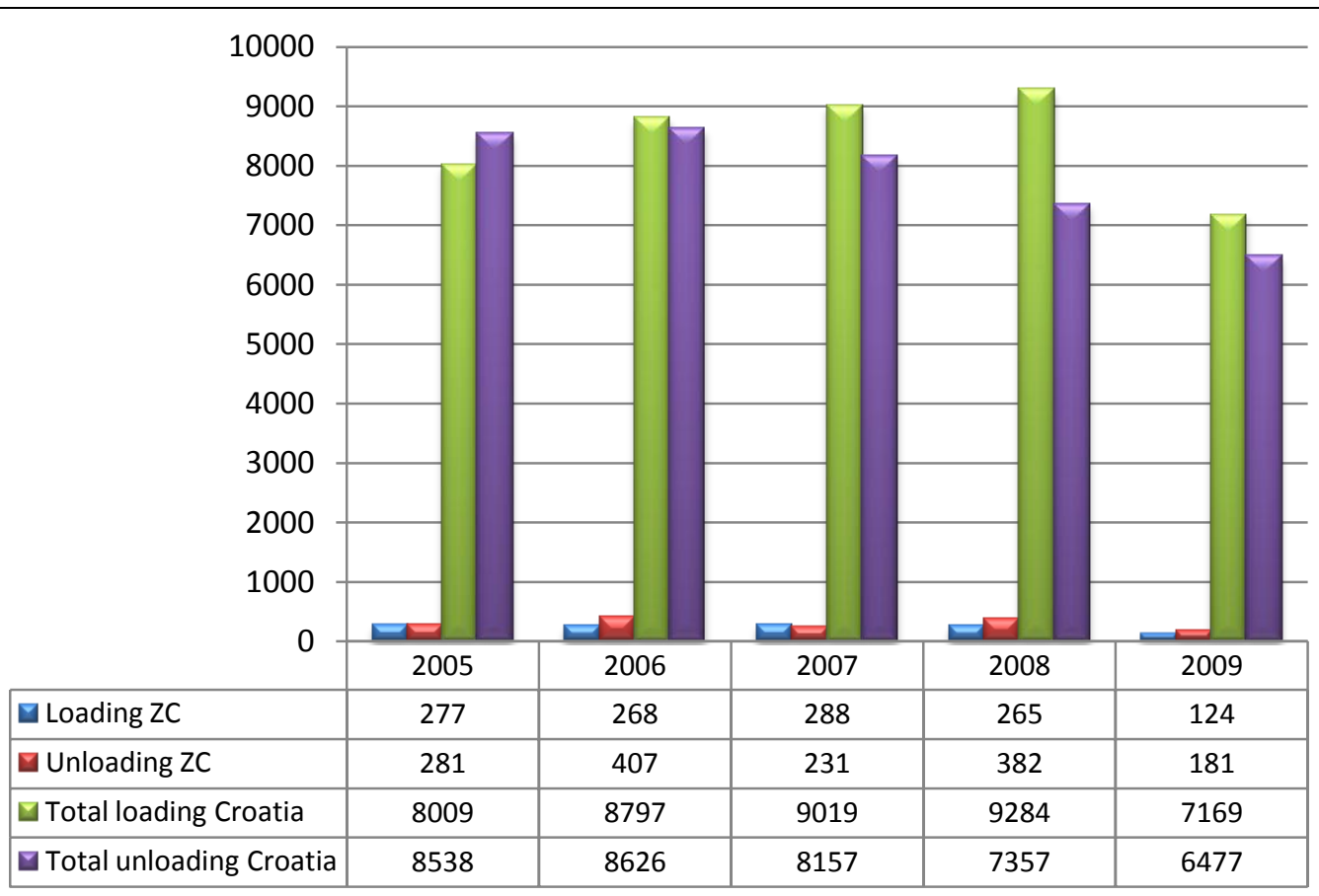

Fig. 3. Rail transport of goods for the City of Zagreb in relation to the total rail traffic of goods for Croatia 
The analysis of the structure of goods flows shows a significant share of transit traffic in the goods flows, separately in road traffic (Table 8). This results from the geo-traffic position of the Republic of Croatia, where the goods flows from the European West towards the South-east interweave, as well as the goods flows from the overseas countries towards Central and South-eastern Europe. This data indicate that the level of goods flows generated in this way will increase in accordance with the increase of the economic activities of the countries that generate these flows, which means primarily the countries of Central and South-eastern Europe. Regarding the forecasts of the economic growth of the countries of Central and South-eastern Europe, that forecast the growth of gross product at a rate between two and four per cent, and also the recovery of the West European countries that gravitate to Croatia, a more intensive increase in the goods flows in transit in the period of the next five years can be expected.

The position of the Zagreb junction is favourable for organising and attracting domestic and transit goods flows, since it provides the connection of the Adriatic ports as a significant generator of transit goods flows and the Central and Southeastern European countries as destination or origin points of the mentioned goods flows. The question is whether the usage condition of the traffic infrastructure on the observed route can match in capacity these scenarios for the goods flows.

\subsection{Level of development of traffic network and possibilities of integrating into main} traffic routes, depth of the aquatorium in port terminals, connecting with at least two traffic branches (road and railway)

The network of Croatian roads is at a satisfactory level, which refers especially to the category of motorways and to the greatest extent of state roads. The motorway capacity is such that it allows undisturbed traffic during the entire year except during the tourist season when short-term congestions are possible, primarily during the tourist exchange intervals.

The high level of investments in road infrastructure over the last decade has enabled connection of the Zagreb junction with almost all the major cities in the Republic of Croatia, as well as in the countries of Central Western and South-eastern Europe.

The connection of the Croatian ports and the Zagreb traffic junction is at a high level when considering the condition of road infrastructure. The motorway network is in good condition, and is being further improved and modernised, and allows transport of big quantities of goods by road transport means in both directions. Further redistribution of goods within the Zagreb area is possible by using the well developed network of state and county roads that connect Zagreb and the surrounding smaller cities and county centres.

Since according to all the EU strategic documents the rail traffic subsystem is the main carrier of the current and future intermodal transport chains, additional criteria have to be processed in order to define the catchment zone of the rail operators. 
The additional criteria are first related to the analysis of technical compatibility of railway systems. The technical compatibility of the system is one of the preconditions for the increase of the railway systems capacity and their competitiveness in relation to other traffic branches.

For the sake of testing the proposed methodology the railway traffic routes in the Republic of Croatia, where the domestic carriers will continue to realise the greatest operation, have been analysed. Since on the observed traffic routes the railway system is planned for the catchment zone of the city of Zagreb as the key carrier of goods flows transport, an additional market segmentation has been carried out. It has been carried out on the studied network for the railway system according to the criterion of the existing supply system, for $25 \mathrm{kV}, 50 \mathrm{~Hz}$. Another criterion is the capacity where the railway locomotive higher productivity is limited on the one hand by the greater mass of trains (gross), and on the other hand maximally long travelled distance in train running $(\mathrm{km})$ or maximal daily time spent in train traction $(\mathrm{h})$. Internal organisational shifts (selection of transport mode, type of locomotive, etc.) by the railway operator can achieve better usage level of the existing infrastructure and the transport of larger amounts of freight. It is thus possible to enlarge the catchment zone, by the possibility of attracting and processing a greater quantity of goods flows on the infrastructure of the nominally equal capacity. An example of such approach to organisation and the possible results has been presented in phases.

In the first phase (PHASE I) on the existing railway route without the change of the traction system the following is proposed:

a) Since the usage of locomotives 1061 is limited to the part of network electrified by $3 \mathrm{kV}$ system, their productivity is significantly lower than the locomotives of the alternative supply system of the 1141 and 1142 series whose productivity in 2007 was on the average daily 287.27 (kgrosskm/day).

In the existing conditions of exploitation on the Rijeka-Lokve section, which represents the most difficult section of the traction of freight trains, it is realistically possible to turn out simultaneously two trains of gross mass of 1,000 tons, which require engagement of four locomotives in the clock-faced timetable.

At the same time the return runs of the zaprežnih locomotives from Lokve to Rijeka need to be taken into consideration, which means that in freight transport six to seven locomotives within an hour can be engaged.

The engagement of locomotives on trains that wait for delivery to Lokve (two in Bakar and two in Rijeka) needs to be taken into consideration as well.

b) On the relation to Šapjane two locomotives for freight traffic are required.

With possible reserve that covers the need for the maintenance and possible breakdowns the maximum number of the required locomotives for freight transport on this relation would be ca. 15 locomotives.

c) Such traction rolling stock would enable maximal freight turn-out of freight from the Rijeka Basin: 
c.1) daily

- in 1 hour there would be 2 trains per ca. 1,000 (t), along the reserve for railway line maintenance $(4 \mathrm{~h})$ and without intervals in which passenger trains operate (8h), in free time capacity of $12 \mathrm{~h}=2 * 12 * 1,000$ which is 24,000 gross daily.

c.2) annually

- at annual level this would amount to ca. $24,000(t) * 30 * 12$, hence ca. $8,640,000$ gross,

- the freight itself would account for approximately $67 \%$ gross i.e. $5,787,800 t$.

In the second phase (PHASE II) on the existing railway route with traction system change and modification of traction vehicles the following is proposed:

d) In the conditions after the change of the traction system the traction of freight trains of gross mass of 1,500t with three locomotives (tandem + banking train) will be possible, which will allow transport performance greater by $50 \%$, for which a larger number of locomotives will be required. These locomotives for the traction of freight trains should be four-axle ones of permanent power not lower than 4MW so that the freight trains could run uphill at a speed of at least $60 \mathrm{~km} / \mathrm{h}$. The increase in the number of trains on the railway line is not possible because of the restriction in the power of feeder stations. If parallel operation of feeder station could be realised, it would be possible to increase the number of trains. With the assumed length of the supply section of $40 \mathrm{~km}$, supported by $15 \mathrm{MW}$ power feeder station, such a section can at the same time accommodate one train running uphill at a speed of $60 \mathrm{~km} / \mathrm{h}$, one train running downhill and possibly one train in the starting phase.

e) Until purchasing new locomotives for the traction of freight trains from the Rijeka Basin for this purpose the locomotives of the series 1141 for the maximal speed of $120 \mathrm{~km} / \mathrm{h}$ can be used. The estimate is that for this purpose 20 new mono-phase locomotives should be purchased. They would be used in the following way:

a) for the traction of gross from Rijeka two trains with three locomotives each which means six of them;

b) besides, there should be in the same hour three locomotives on the return run towards Rijeka (on a train hour);

c) on the relation to Šapjane two locomotives will be required;

d) for freight transport, in the preparation phase for the dispatch of trains from Rijeka i.e. Bakar six more locomotives will be required;

e) for the reserve for the purpose of maintenance three more locomotives in the operation rolling stock are required.

f) Such traction rolling stock would enable the following capacity for the turnout of freight from the Rijeka Basin:

f.1) daily

- daily $12 * 3,000$ t which means 36,000 gross 
Mlinaric, T.J.; Rogic, K. \& Rozic, T.: Methodology for Determining Dry Port Syst...

f.2) annually

- annually this would amount to $36,000 * 365$, which means $13,140,000$ gross,

- the freight itself would account for approximately $67 \%$ gross which means $(13,140,000 * 0.67) 8,803,800$ (net t) without Šapjane and without return gross towards Rijeka.

This technological solution would enable high-quality processing both of the existing and the future gross, and besides it is obvious that the modal split regarding all three scenarios would be feasible.

\subsection{Impact on the environment}

The evaluation of the ecological impact of traffic on the environment is one of the possible criteria of evaluating the traffic service. Besides, the impact of traffic activities on the environment is the cause also of the changes in the transportation concept and the introduction of the systems that have minimal negative impacts on the environment. The biggest sources of negative impacts on the environment are the exhaust gases generated by the combustion of fuels, with road traffic being one of the greatest polluters if considering the volume of exhaust gases per ton of carried freight. Railway traffic, and especially water transport regarding this criterion release significantly smaller quantity of exhaust gases.

Within the frame of the European Commission the emphasis of the traffic policy lies on the shifting of the transport of goods to railway infrastructure, strengthening of intermodal transport, and where possible, usage of water transport. The transfer of transloading units from one transport mode to another is most often performed at junctions where the traffic branches meet, which means ports, logistic distribution centres and intermodal terminals. Often the intermodal terminals are parts of the ports, and logistic and distribution centres.

With this approach the role of dry port terminals as starting and terminal points of intermodal transport chains is redefined.

According to the protocol adopted in Kyoto Croatia has committed to reduce the carbon dioxide emissions into the atmosphere, which should lead also to certain changes in the traffic policy. This requires the construction of a certain number of intermodal terminals. An important role in this network should belong to the future dry port of the Port of Rijeka, since it is the most important traffic junction in the Republic of Croatia.

It is precisely this that we quantify through the internalisation of the external costs, which understands not only the method of charging external costs, but also their reduction, resulting in the necessary balancing of the competitiveness of individual traffic branches. The objective of internalisation should be the shifting of demand to railways, which, regarding all its characteristics is the environmentally friendliest transport mode. It should be emphasised that the mobility of the society should not be reduced or prevented, since this represents the basic social dimension. The methodology contains also the calculation of the external costs based on the comparison of the transport of the same quantity of gross by different traffic 
subsystems and harmful emissions and negative effects on the environment, which are generated by the selected transport means.

\subsection{Size of areas planned for the terminal}

According to the proposed methodology for determining of the necessary area, two complementary technological and logistic units have to be analysed. The first analysis refers to the technological and traffic function of the terminal, where the following has to be elaborated within the proposed area of this module:

- necessary number and lengths of tracks,

- necessary number and lengths of freight handling ramps,

- tracks capacities at railway stations that will deliver/dispatch the processed gross freight from the network,

- necessary number and lengths of cranes, and

- necessary number of places for road heavy vehicles and the necessary are for processing of freight delivered by road heavy vehicles.

The other complementary unit at the terminal is the one that refers to logistic subsystems. According to the methodology this unit depends on:

- container terminal,

- Ro-La terminal,

- general purpose warehouses,

- refrigerating storage houses (conditioned warehouses),

- warehouses for dangerous goods,

- terminal for trucks,

- other accompanying facilities.

\section{Conclusion}

The methodology of defining the dry ports system on the traffic network is based on an entire series of previous studies of individual technological and logistic criteria for the formation of respective intermodal transport chains. The crucial problem that tried to be solved with this methodology was to determine and quantify the correlation between the mentioned parameters. Only through their quantified interrelation based on the precise definition of the traffic demand can the availability of the traffic infrastructure capacities be defined regarding the studied catchment areas.

In this paper the mentioned correlation has been determined in the actual environment of the Croatian traffic network. The study was carried out on the traffic relation the Port of Rijeka - the city of Zagreb, where the proposed methodology has also been tested. Apart from proving the acceptability of such a methodological approach, the result of the carried out research resulted also in the offering of a really original solution of the dry port of the Port of Rijeka. The methodology has, namely, shown that the area of the city of Zagreb can serve as the dry port of the Port of 
Mlinaric, T.J.; Rogic, K. \& Rozic, T.: Methodology for Determining Dry Port Syst...

Rijeka, which in the previous European practice was neither tested nor has it been proven as a technically and technologically acceptable solution.

Besides, following the EU traffic policy, this solution in the case study has recognised railways as the environmentally friendliest transport mode and it is therefore that the maximum volume of traffic tends to be directed to the railway, in order to alleviate the burden on the roads and achieve maximum efficiency related to the saving of energy and environmental protection. In order to achieve this on the territory of the Republic of Croatia the rail system that is not capable of competing with other transport branches needs to be transformed.

\section{References}

Mlinaric, T. J.; Plesa, T., Baric, D.:(2008). Optimizing the Technological Processes of RO-La Transport, Chapter 43 in DAAAM International Scientific Book 2008, pp. 509-524, B. Katalinic (Ed.), Published by DAAAM International, ISBN 978-3-901509-66-7, Vienna, Austria

Roso, V. (2009). The Dry Port Concept, Department of Technology Management and Economics, Chalmers University of Technology, ISBN 978-91-7385-338-5, Göteborg

Ferrari, C., Parola, F., Gattorna, E. (2010). Measuring the quality of port hinterland accessibility: The Ligurian case, Transport Policy, Vol. 18, No. 2, (March 2011), 382-391, ISSN: 0967-070X

Notteboom, T. (2010). Concentration and the formation of multi-port gateway regions in the European container port system: an update, Journal of Transport GeoFig.y, Vol. 18, No. 4, (July 2010), 567-583, ISSN: 0966-6923

Rodrigue J., P., Notteboom, T. (2010). Foreland-based regionalization: Integrating intermediate hubs with port hinterlands, Research in Transportation Economics, Vol. 27, No. 1, (2010), 19-29, ISSN: 0739-8859

Rodrigue J., P., Debrie, J., Fremont, A., Gouvernal, E. (2010). Functions and actors of inland ports: European and North American dynamics, Journal of Transport GeoFig.y, Vol. 18, No. 4, (July 2010), 519-529, ISSN: 0966-6923

Roso, V. (2007). Evaluation of the dry port concept from an environmental perspective: A note, Transportation Research Part D: Transport and Environment, Vol. 12, No. 7, (October 2007), 523-527, ISSN: 1361-9209

Roso, V., Woxenius, J., Olandersson G. (2006). Organisation of Swedish dry port terminals, ISSN 0283-4421, Göteborg 